\title{
Home Financing through the Musharakah Mutanaqisah Contracts: Some Practical Issues
}

\author{
Ahamed Kameel Mydin Meera and Dzuljastri Abdul Razak \\ Associate Professor and Senior Academic Fellow respectively at the \\ Department of Business Administration, Kulliyyah of Economics and \\ Management Sciences, \\ International Islamic University Malaysia, Malaysia \\ akameel@iiu.edu.my-dzuljastri@iiu.edu.my
}

\begin{abstract}
The authors compare the al-Bay' Bithaman Ajil (BBA) and the Musharakah Mutanaqisah Partnership (MMP) contracts. The BBA, a murabahah contract, was argued to be problematic and even unIslamic for long-duration contracts. The MMP contract which is a combination of musharakah (partnership) and ijarah (rental) contracts was argued to be a more appealing alternative. In the MMP, the equity of the financier diminishes progressively while, in accordance, the equity of the customer grows. Unlike for the BBA contract, scholars are consensus on the Shari'ah permissibility of the MMP contract. A mathematical derivation for the MMP showed that the formula for the MMP to be similar to the formula used in conventional loans but nonetheless with the interest rate replaced with the rental rate. Therefore, one major advantage of MMP was argued to be that it can avoid interest ( $r i b a)$ totally. Also, unlike under the BBA, the balance of financing, at any point in time, never exceeds the original price of the asset. Nevertheless, some practical issues need to be addressed particularly the means of estimating the rental rate, tax issues, defaults and asset value appreciation. This paper discusses these issues. When not profitable for the banks, when rental rates fall short of interest rates, the MMP can be implemented through cooperatives, which can be also an investment avenue for members.
\end{abstract}




\section{Introduction}

Meera and Abdul Razak (2005) argued the Musharakah Mutanaqisah Partnership (MMP) contract as a better Islamic financing alternative for long durations compared with the al-Bay' Bithaman Ajil (BBA) contract. While the $\mathrm{BBA}$ is popular in countries like Malaysia, Indonesia and Brunei, it has proven to be quite unsatisfactory to the customers and bankers.

Customers are particularly not happy when it comes to early redemption or in the event of default. In these cases, the BBA contract always carries a higher financing balance compared to the conventional loan of similar APR. The recent Affin Bank vs. Zulkifli is a landmark case, (ISRA Monograph Series, 1:2009) Appropriately, the Middle Eastern Shari'ah scholars disapprove of the BBA contract, citing that it is similar to the conventional loans.

For the bankers, the BBA fixed financing mode brings about liquidity management problems. This is because its cost of funds, particularly the deposit rate is based on floating rate while its income is predominantly based on fixed rate murabahah and ijarah contracts where the rate is fixed. This mismatch in duration can be much of concern and hence many Islamic banks have resorted to 'mind boggling' profit rate swaps ${ }^{(1)}$ to solve this. Generally the Islamic bank would swap its fixed rate murabahah cash flows for a floating rate cash flow to match its cost structure. Recent innovation to the BBA by allowing it to be based on variable rate is also meant solve this mismatch.

In summary, the BBA home financing, can be said to be almost similar to the conventional financing but the customer is likely to end up with higher financing costs in case of early redemption or defaults.

Due to arbitraging activities, the BBA has converged to the conventional mode where the computational formulas are similar to the conventional and where the profit rate tracks the market interest rate. Instead of charging the customer interest, financiers charge a profit rate that is dependent on the market interest rate.

To address the above issues, Meera and Abdul Razak (2005) argued for the MMP as a better alternative to the BBA.

(1) The profit rate swap is nothing other than interest rate swap. It is mind boggling to the Shariah scholar because it involves the transaction where two parties would lend money to each other for the same principal amount but at different rates - one floating, one fixed. 


\section{The Musharakah Mutanaqisah Partnership (MMP) Concept}

The Musharakah Mutanaqisah Partnership (MMP) contract, on the other hand, is based on a diminishing partnership concept. The MMP consists of three contracts - i.e. musharakah, ijarah and bay'. First, the customer enters into a partnership (musharakah) under the concept of 'Shirkat-al-Milk' (joint ownership) agreement with the bank to co-own the asset being financed. Second, the bank leases its share in the asset ownership to the customer under the concept of ijarah. For example, customer pays $20 \%$ of the asset cost as the initial share to co-own the asset whilst the bank provides for the balance of $80 \%$. Third, the customer gradually buys the bank's $80 \%$ share at an agreed portion periodically until the asset is fully owned by the customer. The periodic rental amounts will be jointly shared between the customer and the bank according to the percentage share holding at the particular times which keeps changing as the customer purchases the financier's share. The customer's share ratio would increase after each rental payment due to the periodic redemption until eventually fully owned by the customer.

Bendjilali and Khan (1995) and Muhammad Taqi Usmani basically agreed on the implementation process of Musharakah Mutanaqisah Partnership. The major advantages of MMP over BBA may be summarized as follows:

1. The MMP is accepted internationally as Shari'ah-compliant whereas the BBA is recognized predominantly in the east, i.e. in Malaysia, Indonesia, and Brunei etc. Thus the MMP is suited for contracts across national borders. The BBA can prove problematic for international financing applications.

2. Unlike under BBA, the value of the house under MMP always reflects the market price and the rental is determined by the market rental values or at a price agreed at the time of acquisition.

3. The return to the BBA is based on a fixed selling price (that uses the prevailing interest rate as the benchmark). But under MMP, the financer need not be tied to a fixed profit rate throughout the financing tenor. This is because the rental rate can be revised periodically to reflect current market conditions. Indeed, as argued earlier, the rental can be tied to some economic variables like Rental Index, House Price Index etc. If a particular index is used, it would be specified in the contract and acceptable to both the customer and bank to avoid gharar.

4. The financier can manage the liquidity risks better as rental payments can be adjusted at the end of each subcontract period. This is not possible under the 
current fixed-rate BBA as the profit rate is constant throughout the entire tenor of financing.

5. Even compared with a floating-rate BBA, the MMP still differs in the balance of financing at any point in time before the end of the contract. Under MMP, the balance can never be larger than the original price/finance of the house. Rebates for early redemption under BBA cannot be specifically stated in the contract.

6. The MMP is a more flexible financing structure than the BBA as the customer can own the property earlier by redeeming faster the principal sum of the financier, without the need to compute rebates ${ }^{(2)}$ as in BBA.

7. In the event of payment defaults, the penalty charges under BBA can be challenged, while under MMP, defaults will cause the equity of financier to remain constant and therefore entitled to higher rental portions when payments made later.

8. If the property is auctioned ${ }^{(3)}$ off due to default, the amount sold would depend on the highest bidder which can be lower than the balance outstanding owed by the customer. In the case of MMP, the bank will ensure that the property is sold at a reasonable value as a lower amount would also affect its own position.

9. Currently many customers opine that the BBA is similar to the conventional loan with some "disadvantages" for the customer particularly for early redemptions.

\subsection{MMP Practical Issues}

In implementing the MMP the first thing that we notice is that its formula turns out to be similar to the conventional loan. The conventional financing uses the standard formula for present value of annuities to compute for the monthly payments, i.e.

$$
\begin{aligned}
& P V=\frac{P m t}{i}\left[1-\frac{1}{(1+i)^{n}}\right] \\
& \text { which gives, } \quad P m t=\frac{i(1+i)^{n} P V}{(1+i)^{n}-1}
\end{aligned}
$$

(2) Which is at the discretion of the bank since fixing the rebate upfront is not allowed in Shari'ah.

(3) Some auction may be manipulated 
Where $\mathrm{PV}=$ present value of the monthly or periodic installments, which is the loan amount itself.

$P m t=$ the monthly or periodic installments (principal and interest).

$i=$ the monthly or periodic interest rate.

$n=$ the number of months or periods.

For the MMP, the monthly payment is given by the formula.

$$
M=\frac{x(1+x)^{n} B_{0}}{(1+x)^{n}-1}
$$

Where $\mathrm{M}=$ the monthly or periodic payments to the bank, that comprises the rental amount and the additional amount being paid in order to redeem the asset early.

$x=$ rental rate, e.g. Monthly rental divided by the original asset price.

$B_{0}=$ the initial contribution of the bank in the purchase price.

$n=$ the number of months or periods for the customer to fully own the asset.

\section{(See Appendix A)}

Comparing equations (1) and (2) show a striking similarity. An obvious advantage from this similarity is that the conventional formulas, and therefore the conventional financial calculators and spreadsheets like Excel can be used for the MMP computations and the preparation of amortization schedules thereof. But the interest rate must be replaced by the rental rate, $x^{(4)}$.

The rental is most suited for use in Islamic finance since it is measured from the true usufruct of the asset, unlike interest charges that are apparently not tied to the asset's usufruct. Hence the rental rate can differ among houses within a same row of houses or among different floors within a condominium block. But interest rates are generally independent from such factors.

\subsection{Scholars' opinions on using rental versus interest in MMP}

In order to ascertain the validity of using actual rental value as an alternative to interest rate, we carried out five semi-structured interviews with scholars in Islamic economics, figh (law) and Shariah advisers of Islamic banks regarding their opinion on using actual rental based on value of property for Musharakah Mutanaqisah home financing in place of interest as a bench mark. In general, they all agreed on the usage of actual rental value of property as an alternative

(4) Appendix C provides a worked example of using conventional calculators for solving MMP problems. 
to interest rate as the former reflects the real property value in the market. Please refer to Appendix B for detail of their opinions.

According to Taqi Usmani (2004), rental must be determined at the time of contract for the whole period of lease. It is permissible that different amounts of rent are fixed for different phases during the lease period, provided that the amount of rent for each phase is specifically agreed upon at the time of affecting a lease. If the rent for a subsequent phase of the lease period has not been determined or has been left at the option of the lessor, the lease is not valid. This is further supported by Wahaba al-Zuhayli (2003) which said that "A sale without naming the price is defective and invalid "One cannot agree to buy or rent something without knowing the price one must pay. He summarizes: "general conditions specify that the sale must not include any of the following six shortcomings... "uncertainty or ignorance (al-jahala), coercion, timerestriction, uncertain specification (gharar al-wasf), harm (al-darar), and corrupting conditions (al-shurut al-mufsidah)".

Currently the practice of setting rental rates by Islamic banks in UK for Musharakah Mutanaqisah is linked to the London Inter-bank Offered Rate (LIBOR). Scholars have argued that setting rental levels in line with market interest rates is not in itself haram. They argued this by analogy, on the basis that it is permitted for a Muslim shopkeeper to make the same percentage of profit selling lemonade as the non-Muslim shopkeeper selling alcohol (Yacuby and Usmani, 1998).

However, we find it difficult to put this analogy to practice following the conditions for rental mentioned by Taqi Usamani (2004) and Wahaba alZuhayli (2003) because using LIBOR as a benchmark would entail uncertainty (gharar) in the pricing of rental as it is not possible to determine future changes in interest rates. This is because LIBOR is determined on daily basis for a specified future period e.g. 5\%p.a for 6 months, a customer would not know what the changes in LIBOR after 6 months resulting in uncertainty in the contract. The validity of the lease contract is further doubtful as the fixing of subsequent rental is entirely at the option of lessor without consultation of the lessee. As mentioned above by Taqi Usmani (2004), the lessor cannot increase the rent unilaterally without the acceptance of the customer and any agreement to this effect is void. If the interest rates increase dramatically, then the rental payments will likewise increase and the customer may find himself locked into the payment of rentals that he cannot afford causing financial burden and hardship to himself and family which is not in line with the objective of Shariah. 


\section{MMP and the Issue of Convergence}

We argued earlier that the differences in the Islamic and conventional financing would cause both financing modes to ultimately converge. Hence it is of no surprise then that the MMP would gain popularity over the BBA since for similar APRs, the amortization schedules for both the MMP and conventional would look exactly the same even including the financing balances at any period in time. Therefore, it is high time that Islamic bankers would move towards the MMP financing. Nevertheless, a new problem is likely to arise with respect to the convergence issue, namely the tendency to substitute the rental rate with the market interest rate. There are a few reasons for this substitution:

1. The bank's cost of funds is likely to be tied to market interest rates.

2. Under convergence, the use of interest rate instead of rental rate would give an amortization schedule similar to conventional financing.

3. The interest rate is usually higher than the rental rate.

4. Tracking rentals can be cumbersome and impose additional costs particularly if services of independent valuers are sought unless there are already national or regional rental indices.

But a truly Islamic financing should avoid interest rates totally and let the values and therefore payments solely be determined by the real economy. This paper provides a solution so as to make the rental rate as robust and variable as the market interest rate as possible.

\subsection{The MMP with Variable Rental Rates}

If the cost of funds to the bank is based on variable rates while the MMP contract's rental rate is fixed for the entire tenor, then the bank may face liquidity risk problems as in the BBA contract. The problem is matching the short duration deposit funds with long duration of the financings. The MMP can be made for flexible by requiring the review of rental periodically, say every five years. This would at least reduce the mismatch problem. An example is provided below:

\section{Example of a Musharakah Mutanaqisah Partnership (MMP) Financing With Varying Rental Rate}

Consider an example where a customer wishes to buy a house priced at RM300, 000. Let's assume that the customer pays 20 percent of the price, i.e. RM60, 000, the financier puts the remaining 80 percent, i.e. RM240, 000. The customer wishes to redeem the financier's share in 20 years. Now assume that 
the rental is agreed upon to be RM1, 500 per month for the first 5 years, but would be reviewed to RM1, 800 for the next 5 years and RM2, 000 for the remaining 10 years.

According to the MMP formulas, if the customer pays RM1, 500 only every month, it would take more than twenty years (precisely 26 years and 11 months $)^{(5)}$ to fully own the house. Therefore, some additional amount is necessary in order to redeem within twenty years:

Here, the rental rate is, $x=\frac{R}{P}=\frac{1500}{300000}=0.005$ and the additional monthly amount needed is

$$
\begin{aligned}
A & =\frac{x\left[P-(1+x)^{n} C_{0}\right]}{(1+x)^{n}-1} \\
& =\frac{0.005\left[300,000-(1.005)^{240} \times 60,000\right]}{(1.005)^{240}-1} \\
& =R M 219.43
\end{aligned}
$$

Therefore, the total monthly payment $=\mathrm{RM} 1,500+\mathrm{RM} 219.43=\mathrm{RM} 1$, 719.43 for the first 5 years ( 60 months).

Table (1) provides the schedule for the above MMP contract. At the end of the $5^{\text {th }}$ year, the balance of financing (financier's equity) is RM203, 759.35 while the customer's equity is RM96, 204.35. Thereafter, the rental would be increased to RM1, 800 per month. The new rental rate is $x=1800 / 300000=$ $0.6 \%$ while the remaining contract period is 15 years or 180 months. The new additional monthly amount can be computed as follows:-

$$
\begin{aligned}
A & =\frac{x\left[P-(1+x)^{n} C_{0}\right]}{(1+x)^{n}-1} \\
& =\frac{0.006\left[300,000-(1.006)^{180} \times 96,240.35\right]}{(1.006)^{180}-1} \\
& =R M 54.31
\end{aligned}
$$

(5) The Normal Financial Calculator can be used to solve this, i.e. $\mathrm{PV}=-240,000 \mathrm{i}=0.5 \% \mathrm{Pmt}=$ $1,500 \mathrm{n}=$ ? 
Table 1. Payments Schedule for Musharakah Mutanaqisah Partnership With Varying Rental Rates.

\begin{tabular}{|c|c|c|c|c|c|c|c|c|c|}
\hline \multirow[b]{2}{*}{ Month } & \multirow[b]{2}{*}{$\begin{array}{c}\text { Monthly } \\
\text { Rent } \\
\text { (RM) }\end{array}$} & \multirow[b]{2}{*}{\begin{tabular}{|c|} 
Monthly \\
Redemption \\
(RM) \\
\end{tabular}} & \multirow[b]{2}{*}{$\begin{array}{c}\text { Total } \\
\text { Payment } \\
(\mathrm{RM})\end{array}$} & \multirow[b]{2}{*}{$\begin{array}{l}\text { Customer's } \\
\text { ratio }\end{array}$} & \multicolumn{2}{|c|}{ Rental Division } & \multirow[b]{2}{*}{$\begin{array}{c}\text { Customer's } \\
\text { Equity (RM) }\end{array}$} & \multirow[b]{2}{*}{$\begin{array}{c}\text { Financier's } \\
\text { Equity } \\
\text { (RM) }\end{array}$} & \multirow[b]{2}{*}{$\begin{array}{c}\text { Financier's } \\
\text { Cashflow } \\
\text { (RM) }\end{array}$} \\
\hline & & & & & Customer & Financier & & & \\
\hline & A & $\mathrm{B}$ & $\mathrm{C}=\mathrm{A}+\mathrm{B}$ & $\mathrm{D}$ & $\mathrm{E}$ & $\mathrm{F}$ & G & $\mathrm{H}$ & \\
\hline 0 & & & & 0.20000 & & & $60,000.00$ & 240,000 & $(240,000)$ \\
\hline 1 & 1500 & 219.43 & 1719.43 & 0.20000 & 300.00 & 1200.00 & 60519.43 & 239480.57 & 1719.43 \\
\hline 2 & 1500 & 219.43 & 1719.43 & 0.20173 & 302.60 & 1197.40 & 61041.46 & 238958.54 & 1719.43 \\
\hline 3 & 1500 & 219.43 & 1719.43 & 0.20347 & 305.21 & 1194.79 & 61566.09 & 238433.91 & 1719.43 \\
\hline 4 & 1500 & 219.43 & 1719.43 & 0.20522 & 307.83 & 1192.17 & 62093.35 & 237906.65 & 1719.43 \\
\hline 5 & 1500 & 219.43 & 1719.43 & 0.20698 & 310.47 & 1189.53 & 62623.25 & 237376.75 & 1719.43 \\
\hline 6 & 1500 & 219.43 & 1719.43 & 0.20874 & 313.12 & 1186.88 & 63155.80 & 236844.20 & 1719.43 \\
\hline . & . & . & . & . & . & . & . & . & - \\
\hline 60 & 1500 & 219.43 & 1719.43 & 0.31848 & 477.72 & 1022.28 & 96240.65 & 203759.35 & 1719.43 \\
\hline 61 & 1800 & 54.31 & 1854.31 & 0.32080 & 577.44 & 1222.56 & 96872.40 & 203127.60 & 1854.31 \\
\hline 62 & 1800 & 54.31 & 1854.31 & 0.32291 & 581.23 & 1218.77 & 97507.95 & 202492.05 & 1854.31 \\
\hline 63 & 1800 & 54.31 & 1854.31 & 0.32503 & 585.05 & 1214.95 & 98147.31 & 201852.69 & 1854.31 \\
\hline . & . & . & . & . & . & . & . & . & . \\
\hline 120 & 1800 & 54.31 & 1854.31 & 0.46935 & 844.83 & 955.17 & 141704.65 & 158295.35 & 1854.31 \\
\hline 121 & 2000 & -79.44 & 1920.56 & 0.47235 & 944.70 & 1055.30 & 142569.91 & 157430.09 & 1920.56 \\
\hline 122 & 2000 & -79.44 & 1920.56 & 0.47523 & 950.47 & 1049.53 & 143440.93 & 156559.07 & 1920.56 \\
\hline 123 & 2000 & -79.44 & 1920.56 & 0.47814 & 956.27 & 1043.73 & 144317.77 & 155682.23 & 1920.56 \\
\hline. &. & $\cdot$ & $\cdot$ & . & . & . & . & . & $\cdot$ \\
\hline 240 & 2000 & -79.44 & 1920.56 & 0.99364 & 1987.28 & 12.72 & 300000.11 & $-0.11 *$ & 1920.56 \\
\hline
\end{tabular}

*Balance not zero due to rounding errors. Using the iterative method, the monthly return to the bank is found to be $0.562337 \%$. Therefore, the IRR $=0.562337 \times 12=6.75 \%$.

Therefore, the new total monthly payment $=$ RM1, $800+$ RM54.31 = RM1, 854.31 for the next 5 years (60 months). The balance of financing (financier's equity) at the end of this period is RM158, 295.35 while the customer's equity is RM141, 704.65. The customer's ownership ratio is $47.235 \%$. If the customer cannot afford to pay the new rental but can only say continue to pay the old rental, then the duration of the remaining contract period would be extended. In the above example, if the customer continues to pay RM1,719.43 per month instead of RM1,854.31 then the new duration of the contract becomes 17 years and 4 months (208 months) ${ }^{(6)}$ instead of the original remaining contract period of 15 years.

(6) Computed as PV $=-203,759.35 \quad i=0.6 \% \quad P m t=1,719.43 \quad n=?$ 
For the remaining ten years (120 months), the rental is fixed at RM2, 000 per month, which gives a rental rate of $x=2000 / 300000=0.6667 \%$. Now, interestingly the new additional amount needed is a negative amount.

$$
\begin{aligned}
A & =\frac{x\left[P-(1+x)^{n} C_{0}\right]}{(1+x)^{n}-1} \\
& =\frac{0.006667\left[300,000-(1.006667)^{120} \times 141,704.65\right]}{(1.006667)^{120}-1} \\
& =-R M 79.44
\end{aligned}
$$

And therefore, the new total monthly payment $=$ RM2, $000-$ RM79.44 = RM1, 920.56 for the last 10 years (120 months). However, if the customer is willing to pay the RM2, 000 rental, then the remaining duration of the contract can be shortened. In this case it would be 9 years and 5 months, i.e. shortened by 7 months.

\subsection{The MMP with Varying Property Value}

The basic MMP contract is a partnership between the financier and the customer in owning a property and then involves the renting of the property by the customer. Periodically the customer also redeems the financier's equity in the said asset until it is fully owned by the customer. In the above section we have seen how the varying rental can be accommodated for.

Some quarters nevertheless pose the question on the value of the property too. If two parties co-own an asset and share its rental income, they should also share the asset's price appreciation, if any. While this may seem acceptable, there are a few issues involved:

1. The MMP involves the redemption of the financier's equity by the customer. Hence by the end of the MMP contract the customer would have acquired the full ownership of the asset and therefore any price appreciation at that moment would fully belong to the customer.

2. An asset should be valued only when there is a sale of the property which would involve the full transfer of ownership. Otherwise the appreciation or depreciation of value would only be on paper ${ }^{(7)}$. Valuation of the asset within the duration of the MMP contract may not be appropriate since a full transfer

(7) It is like owning stocks. One need not pay taxes on stock capital gains simply because prices have gone up until the stocks are liquidated. When stocks are sold, only then the capital gains (losses) are realized. 
does not take place at the moment of valuation. Indeed the MMP involves gradual transfer of ownership along the entire duration of the MMP.

3. If periodic valuation of the asset, just like the rental, is agreed upon then it should involve both appreciation and depreciation. Normally, banks do not want to take this risk.

While we do not favour the valuation of the property during the contract tenor, but to honor the opinion of those who think it appropriate to do so, we provide an example for its computation. While rental can be determined upfront, it may not be appropriate to estimate the future value of the asset upfront. Hence valuation should be done at the times agreed upon. Let us say in our earlier example, valuations are agreed to be done every five years and were observed as below. Here the entire contract can be viewed as a series of four MMP contracts.

\begin{tabular}{|c|c|c|}
\hline $\begin{array}{c}\text { Period } \\
\text { Month }\end{array}$ & $\begin{array}{c}\text { Rental } \\
\text { RM }\end{array}$ & $\begin{array}{c}\text { House Value at the end of } \\
\text { Period (RM) }\end{array}$ \\
\hline $1-60$ & 1,500 & 360,000 \\
\hline $61-120$ & 1,800 & 400,000 \\
\hline $121-180$ & 2,000 & 440,000 \\
\hline $181-240$ & 2,000 & 460,000 \\
\hline
\end{tabular}

Let us assume that at the end of the fifth year, as the rental was reviewed from RM1,500 to RM1,800 monthly, the value of the house had appreciated to RM360,000. At that point, the ownership ratios of the customer and the bank were $32.08 \%$ and $67.92 \%$ respectively. Therefore, the capital appreciation would be shared according to these ratios and the equity of the customer and the bank would then be RM115,488 and RM244,512 respectively. At this new value, the rental of RM1,800 per month gives a rental rate of $0.5 \%$ or $6 \%$ yearly. The new amortization schedule would now be as given in Table (2). The customer's new monthly instalment is RM2,063.33 which is much higher than the previous RM1,719.63. Computations for the rest of the period are as in the table.

\subsection{Cases of Redemption, Default and Termination of Contract}

In the case of early redemption where the customer does not intend to leave the house e.g. at end of 10 years for a 20 years tenure, the redemption amount will be based on the balance outstanding and revaluation of property is thus not needed. In the case of death of the partner, law of inheritance would apply and this can be further mitigated through takaful insurance policy. 
Table 2. Payments Schedule for Musharakah Mutanaqisah Partnership With Varying Rental Rates and Periodic Asset Valuation.

\begin{tabular}{|c|c|c|c|c|c|c|c|c|c|}
\hline \multirow[b]{2}{*}{ Month } & \multirow[b]{2}{*}{$\begin{array}{c}\text { Monthly } \\
\text { Rent } \\
\text { (RM) }\end{array}$} & \multirow[b]{2}{*}{$\begin{array}{c}\text { Monthly } \\
\text { Redemption } \\
\text { (RM) }\end{array}$} & \multirow[b]{2}{*}{$\begin{array}{c}\text { Total Payment } \\
\text { (RM) }\end{array}$} & \multirow[b]{2}{*}{$\begin{array}{c}\text { Customer's } \\
\text { ratio }\end{array}$} & \multicolumn{2}{|c|}{ Rental Division } & \multirow[b]{2}{*}{$\begin{array}{c}\text { Customer's } \\
\text { Equity (RM) }\end{array}$} & \multirow[b]{2}{*}{$\begin{array}{l}\text { Financier's } \\
\text { Equity (RM) }\end{array}$} & \multirow[b]{2}{*}{$\begin{array}{c}\text { Financier's } \\
\text { Cashflow } \\
\text { (RM) }\end{array}$} \\
\hline & & & & & Customer & Financier & & & \\
\hline & A & B & $\mathrm{C}=\mathrm{A}+\mathrm{B}$ & $\mathrm{D}$ & E & $\mathrm{F}$ & G & $\mathrm{H}$ & \\
\hline 0 & & & & 0.20000 & & & $60,000.00$ & 240,000 & $(240,000)$ \\
\hline 1 & 1500 & 219.43 & 1719.43 & 0.20000 & 300.00 & 1200.00 & 60519.43 & 239480.57 & 1719.43 \\
\hline 2 & 1500 & 219.43 & 1719.43 & 0.20173 & 302.60 & 1197.40 & 61041.46 & 238958.54 & 1719.43 \\
\hline 3 & 1500 & 219.43 & 1719.43 & 0.20347 & 305.21 & 1194.79 & 61566.09 & 238433.91 & 1719.43 \\
\hline 4 & 1500 & 219.43 & 1719.43 & 0.20522 & 307.83 & 1192.17 & 62093.35 & 237906.65 & 1719.43 \\
\hline 5 & 1500 & 219.43 & 1719.43 & 0.20698 & 310.47 & 1189.53 & 62623.25 & 237376.75 & 1719.43 \\
\hline 6 & 1500 & 219.43 & 1719.43 & 0.20874 & 313.12 & 1186.88 & 63155.80 & 236844.20 & 1719.43 \\
\hline . & . & . & . & . & . & . & . & . & . \\
\hline . & . & . & . & . & . & . & . & . & . \\
\hline 60 & 1500 & 219.43 & 1719.43 & 0.31848 & 477.72 & 1022.28 & 96240.65 & 203759.35 & 1719.43 \\
\hline 61 & 1800 & 263.33 & 2063.33 & 0.32080 & 577.44 & 1222.56 & 116328.77 & 243671.23 & 2063.33 \\
\hline 62 & 1800 & 263.33 & 2063.33 & 0.32314 & 581.64 & 1218.36 & 117173.74 & 242826.26 & 2063.33 \\
\hline 63 & 1800 & 263.33 & 2063.33 & 0.32548 & 585.87 & 1214.13 & 118022.94 & 241977.06 & 2063.33 \\
\hline . & . & . & . & . & . & . & . & . & . \\
\hline . & . & . & . & . & . & . & . & . & . \\
\hline 120 & 1800 & 263.33 & 2063.33 & 0.48061 & 865.10 & 934.90 & 174148.55 & 185851.45 & 2063.33 \\
\hline 121 & 2000 & 292.57 & 2292.57 & 0.48375 & 967.50 & 1032.50 & 194760.07 & 205239.93 & 2292.57 \\
\hline 122 & 2000 & 292.57 & 2292.57 & 0.48690 & 973.80 & 1026.20 & 196026.44 & 203973.56 & 2292.57 \\
\hline 123 & 2000 & 292.57 & 2292.57 & 0.49007 & 980.13 & 1019.87 & 197299.14 & 202700.86 & 2292.57 \\
\hline . & . & . & . & . & . & . & . & . & . \\
\hline . & . & . & . & . & . & . & . & . & . \\
\hline 150 & 2000 & 292.57 & 2292.57 & 0.58180 & 1163.59 & 836.41 & 234175.08 & 165824.92 & 2292.57 \\
\hline 151 & 2000 & 292.57 & 2292.57 & 0.58544 & 1170.88 & 829.12 & 235638.53 & 164361.47 & 2292.57 \\
\hline . & . & . & . & . & . & . & . & . & . \\
\hline . & . & . & . & . & . & . & . & . & . \\
\hline 180 & 2000 & 292.57 & 2292.57 & 0.69931 & 1398.62 & 601.38 & 281415.12 & 118584.88 & 2292.57 \\
\hline 181 & 2000 & 488.87 & 2488.87 & 0.70354 & 1407.08 & 592.92 & 311453.35 & 128546.65 & 2488.87 \\
\hline 182 & 2000 & 488.87 & 2488.87 & 0.70785 & 1415.70 & 584.30 & 313357.92 & 126642.08 & 2488.87 \\
\hline 183 & 2000 & 488.87 & 2488.87 & 0.71218 & 1424.35 & 575.65 & 315271.14 & 124728.86 & 2488.87 \\
\hline . & . & . & . & . & . & . & . & . & . \\
\hline . & . & . & . & . & . & . & . & . & . \\
\hline 240 & 2000 & 488.87 & 2488.87 & 0.99437 & 1988.74 & 11.26 & 440000.04 & $-0.04 *$ & 2488.87 \\
\hline
\end{tabular}

*Balance not zero due to rounding errors.

Using the iterative method, the monthly return to the bank is found to be $0.671594 \%$

Therefore, the IRR $=0.671594 \times 12=8.0591 \%$ 
A revaluation of the property would take place when the customer intends to leave the house. The revaluation price will be used to offset the outstanding amount and the residual amount will be shared between the customer and the bank based on the prevailing profit sharing ratio. Like wise in cases of default, the house will be sold in the market and the proceeds will be divided between the customer and the bank after deducting all outstanding arrears, liquidation costs including legal costs etc.

Let us assume that the customer defaults after making the $150^{\text {th }}$ monthly rental. At that point the customer's and bank's equity ratios in the house are $58.544 \%$ and $41.456 \%$ respectively. Also assume that at that point, the market price of the house is RM420,000. Therefore, the customer's and bank's portions are RM245,884.80 and RM174,115.20 respectively. But of course, before this division, liquidation costs should have been deducted first. The IRR for the bank in this case (assuming zero liquidation costs) is $8.3 \%$. The higher figure is due to the price appreciation.

In the event of default, any arrears in rental due from customer should also be deducted before the customer's portion is rendered. Rental arrears should also be calculated based on the above ratios. For example if the customer defaulted on three months' rental totaling RM6,000 then the bank's portion in it is RM2,487.36 (i.e. RM6,000 x 0.41456) and this amount should be deducted before the remainder of the customer's portion in the selling price and the balance is returned to the customer.

\section{Estimating the New Rental}

From the above example it is obvious that the MMP formulas can be easily adapted for use in varying rental rates. But estimating the rental is what could prove cumbersome or costly. Some MMP operators use the services of independent real estate agents to provide them with the estimates; sometimes using average of as many as three agents' estimates in order to be more just. But all these can impose additional cost on bank and the customer.

This paper suggests the use of rental indices or house price indices in order to estimate the new rentals without having to bear the cost of using the services of real estate agents. Nonetheless, using indices would cause the loss of some accuracy. Prices and rental of real estate properties are sensitive to many factors. Even within the same locality, particular location can affect prices and rentals. Other than characteristics of the property like floor size, number of rooms, single storey or double storey, corner or intermediate etc., its location relative to school, shops, LRT, hospital, mosque, sewage etc can also affect prices and rentals, (Dunse and Jones, 1998). While an index may give the 
average rental in a locality, specific factors like those mentioned should also be taken into consideration in order to get a better rental estimate fair to both sides.

\subsection{Estimating the Rental Rate}

This section looks at the empirical data from selected areas in Malaysia regarding rental rates and interest rates and attempts to come up with a regression model for estimating rental rates. Such models can then be used for obtaining rental rates to be used in the MMP computations without having to employ the services of property valuers.

Table (3) provides the average gross rental yields and the interest rates for properties in Kuala Lumpur for the period 1984 to 2005. It is clear from the Table that the rental yields for all categories of houses are generally lower than the BLR and the average lending rate. Only condominiums have shown to fetch higher rental yields than the market interest rates. The average differences of the rental yields compared to the average lending rates are provided in Table (4). The lending rate is on average a substantial $4.49 \%, 4.65 \%$ and $4.10 \%$ higher than the rental yields for single storey, double storey and double storey semidetached houses respectively. Nonetheless, interestingly the rental yields for condominiums were higher than both the BLR and the average lending rate. The condominiums rental yield was on average $1.08 \%$ and $2.10 \%$ higher than the average lending rate and BLR respectively.

An analysis of the correlation matrix in Table (5) between the variables shows some interesting results. Firstly, the interest rates are positively correlated only with the yields of higher end properties, i.e. double storey semidetached and condominiums. Interestingly, the interest rates were negatively correlated to the yields of single storey and double storey houses. Other than the BLR which is also an interest rate, the average lending rate is the highest correlated with the yields of condominiums with a correlation of 0.5219 . It seems that investors in only the higher end properties adjust the rental in accordance with the changes in the market interest rate.

\section{Conclusion}

This paper pointed out some practical issues that need to be addressed with the implementation of MMP particularly that affect changes in rental rates; revaluation of property; redemption, defaults, termination of contract and proposed solutions in dealing with these situations. 
Table 3. Gross Rental Yields and Interest Rates Kuala Lumpur.

\begin{tabular}{|c|c|c|c|c|c|c|}
\hline & & & & & & Average \\
\hline Year & Storey & $\begin{array}{l}\text { Double } \\
\text { Storey }\end{array}$ & $\begin{array}{l}\text { Double Storey } \\
\text { Semi-D }\end{array}$ & Condominium & BLR & Lending rate \\
\hline 1984 & $3,87 \%$ & $4,07 \%$ & $4,32 \%$ & & $12,25 \%$ & $12,80 \%$ \\
\hline 1985 & $3,75 \%$ & $4,17 \%$ & $4,47 \%$ & & $10,75 \%$ & $12,10 \%$ \\
\hline 1986 & $5,23 \%$ & $3,44 \%$ & $3,97 \%$ & . & $10,00 \%$ & $12,02 \%$ \\
\hline 1987 & $4,77 \%$ & $5,23 \%$ & $5,21 \%$ & $14,55 \%$ & $7,50 \%$ & $9,73 \%$ \\
\hline 1988 & $5,01 \%$ & $4,78 \%$ & $5,50 \%$ & $8,98 \%$ & $7,00 \%$ & $8,95 \%$ \\
\hline 1989 & $5,01 \%$ & $4,78 \%$ & $5,50 \%$ & $8,98 \%$ & $6,99 \%$ & $8,70 \%$ \\
\hline 1990 & $5,01 \%$ & $4,78 \%$ & $5,50 \%$ & $8,98 \%$ & $7,49 \%$ & $8,99 \%$ \\
\hline 1991 & $4,85 \%$ & $4,53 \%$ & $6,00 \%$ & $10,50 \%$ & $8,68 \%$ & $9,72 \%$ \\
\hline 1992 & $4,90 \%$ & $4,56 \%$ & $7,95 \%$ & $10,73 \%$ & $9,29 \%$ & $10,29 \%$ \\
\hline 1993 & $5,40 \%$ & $5,26 \%$ & $8,35 \%$ & $10,56 \%$ & $8,22 \%$ & $9,65 \%$ \\
\hline 1994 & $5,44 \%$ & $5,48 \%$ & $6,95 \%$ & $9,13 \%$ & $6,83 \%$ & $8,24 \%$ \\
\hline 1995 & $4,70 \%$ & $4,81 \%$ & $6,80 \%$ & $11,02 \%$ & $8,03 \%$ & $9,28 \%$ \\
\hline 1996 & $3,24 \%$ & $3,70 \%$ & $4,70 \%$ & $10,40 \%$ & $9,18 \%$ & $10,12 \%$ \\
\hline 1997 & $3,24 \%$ & $3,70 \%$ & $4,70 \%$ & $8,89 \%$ & $10,33 \%$ & $11,51 \%$ \\
\hline 1998 & $4,52 \%$ & $4,30 \%$ & $3,50 \%$ & $8,89 \%$ & $8,04 \%$ & $9,72 \%$ \\
\hline 1999 & $4,66 \%$ & $4,26 \%$ & $4,50 \%$ & $9,02 \%$ & $6,79 \%$ & $7,75 \%$ \\
\hline 2000 & $4,66 \%$ & $4,26 \%$ & $4,50 \%$ & $9,02 \%$ & $6,78 \%$ & $7,46 \%$ \\
\hline 2001 & $4,95 \%$ & $4,03 \%$ & $3,40 \%$ & $9,05 \%$ & $6,39 \%$ & $6,67 \%$ \\
\hline 2002 & $4,95 \%$ & $4,03 \%$ & $3,40 \%$ & $9,05 \%$ & $6,39 \%$ & $6,51 \%$ \\
\hline 2003 & $3,80 \%$ & $4,07 \%$ & $3,00 \%$ & $8,24 \%$ & $6,00 \%$ & $6,11 \%$ \\
\hline 2004 & $3,80 \%$ & $4,07 \%$ & $3,00 \%$ & $8,24 \%$ & $5,98 \%$ & $5,98 \%$ \\
\hline 2005 & $3,95 \%$ & $3,82 \%$ & $3,00 \%$ & $7,81 \%$ & $6,20 \%$ & $6,12 \%$ \\
\hline Average & $4,53 \%$ & $4,37 \%$ & $4,92 \%$ & $9,58 \%$ & $7,96 \%$ & $9,02 \%$ \\
\hline $\begin{array}{l}\text { Std } \\
\text { Deviation }\end{array}$ & $0,66 \%$ & $0,54 \%$ & $1,55 \%$ & $1,50 \%$ & $1,72 \%$ & $2,03 \%$ \\
\hline
\end{tabular}


Table 4. Differences between Average Lending Rates and Gross Rental Yields Kuala Lumpur.

\begin{tabular}{|c|c|c|c|c|c|c|}
\hline Year & $\begin{array}{l}\text { Single } \\
\text { Storey }\end{array}$ & $\begin{array}{l}\text { Double } \\
\text { Storey }\end{array}$ & $\begin{array}{c}\text { Double } \\
\text { Storey } \\
\text { Semi-D } \\
\end{array}$ & Condominium & $\begin{array}{c}\text { ALR minus } \\
\text { BLR }\end{array}$ & $\begin{array}{c}\text { BLR minus } \\
\text { Condo Rental } \\
\text { Yield } \\
\end{array}$ \\
\hline 1984 & $8,93 \%$ & $8,73 \%$ & $8,48 \%$ & . & $0,55 \%$ & \\
\hline 1985 & $8,35 \%$ & $7,93 \%$ & $7,63 \%$ & . & $1,35 \%$ & \\
\hline 1986 & $6,79 \%$ & $8,58 \%$ & $8,05 \%$ & . & $2,02 \%$ & \\
\hline 1987 & $4,96 \%$ & $4,50 \%$ & $4,52 \%$ & $-4,82 \%$ & $2,23 \%$ & $-7,05 \%$ \\
\hline 1988 & $3,94 \%$ & $4,17 \%$ & $3,45 \%$ & $-0,03 \%$ & $1,95 \%$ & $-1,98 \%$ \\
\hline 1989 & $3,69 \%$ & $3,92 \%$ & $3,20 \%$ & $-0,28 \%$ & $1,71 \%$ & $-1,99 \%$ \\
\hline 1990 & $3,98 \%$ & $4,21 \%$ & $3,49 \%$ & $0,01 \%$ & $1,50 \%$ & $-1,49 \%$ \\
\hline 1991 & $4,87 \%$ & $5,19 \%$ & $3,72 \%$ & $-0,78 \%$ & $1,04 \%$ & $-1,82 \%$ \\
\hline 1992 & $5,39 \%$ & $5,73 \%$ & $2,34 \%$ & $-0,44 \%$ & $1,00 \%$ & $-1,44 \%$ \\
\hline 1993 & $4,25 \%$ & $4,39 \%$ & $1,30 \%$ & $-0,91 \%$ & $1,43 \%$ & $-2,34 \%$ \\
\hline 1994 & $2,80 \%$ & $2,76 \%$ & $1,29 \%$ & $-0,89 \%$ & $1,41 \%$ & $-2,30 \%$ \\
\hline 1995 & $4,58 \%$ & $4,47 \%$ & $2,48 \%$ & $-1,74 \%$ & $1,25 \%$ & $-2,99 \%$ \\
\hline 1996 & $6,88 \%$ & $6,42 \%$ & $5,42 \%$ & $-0,28 \%$ & $0,94 \%$ & $-1,22 \%$ \\
\hline 1997 & $8,27 \%$ & $7,81 \%$ & $6,81 \%$ & $2,62 \%$ & $1,18 \%$ & $1,44 \%$ \\
\hline 1998 & $5,20 \%$ & $5,42 \%$ & $6,22 \%$ & $0,83 \%$ & $1,68 \%$ & $-0,85 \%$ \\
\hline 1999 & $3,09 \%$ & $3,49 \%$ & $3,25 \%$ & $-1,27 \%$ & $0,96 \%$ & $-2,23 \%$ \\
\hline 2000 & $2,80 \%$ & $3,20 \%$ & $2,96 \%$ & $-1,56 \%$ & $0,68 \%$ & $-2,24 \%$ \\
\hline 2001 & $1,72 \%$ & $2,64 \%$ & $3,27 \%$ & $-2,38 \%$ & $0,28 \%$ & $-2,66 \%$ \\
\hline 2002 & $1,56 \%$ & $2,48 \%$ & $3,11 \%$ & $-2,54 \%$ & $0,12 \%$ & $-2,66 \%$ \\
\hline 2003 & $2,31 \%$ & $2,04 \%$ & $3,11 \%$ & $-2,13 \%$ & $0,11 \%$ & $-2,24 \%$ \\
\hline 2004 & $2,18 \%$ & $1,91 \%$ & $2,98 \%$ & $-2,26 \%$ & $0,00 \%$ & $-2,26 \%$ \\
\hline 2005 & $2,17 \%$ & $2,30 \%$ & $3,12 \%$ & $-1,69 \%$ & $-0,08 \%$ & $-1,61 \%$ \\
\hline Average & $4,49 \%$ & $4,65 \%$ & $4,10 \%$ & $-1,08 \%$ & $1,06 \%$ & $-2,10 \%$ \\
\hline $\begin{array}{l}\text { Std } \\
\text { Deviation }\end{array}$ & $2,21 \%$ & $2,12 \%$ & $2,08 \%$ & $1,54 \%$ & $0,68 \%$ & $1,53 \%$ \\
\hline
\end{tabular}

Table 5. The Correlation Matrix between the Rental Yields and Interest Rates.

\begin{tabular}{|l|c|c|c|c|c|c|}
\hline & SS & DS & DSSD & Condo & BLR & ALR \\
\hline SS & 1 & & & & & \\
\hline DS & 0.615952869 & 1 & & & & \\
\hline DSSD & 0.495512227 & 0.721509033 & 1 & & & \\
\hline Condo & 0.223357253 & 0.497778003 & 0.484285081 & 1 & & \\
\hline BLR & -0.304341179 & -0.239105695 & 0.215673069 & 0.387622296 & 1 & \\
\hline ALR & -0.116503069 & -0.044759391 & 0.347073901 & 0.521904316 & 0.947458002 & 1 \\
\hline
\end{tabular}


We have shown that increase in rental rates would reduce the additional share to be acquired by the customer in subsequent years. If the customer cannot afford to pay the new rental and choose to continue paying the old rental, the duration of the remaining contract would be extended. As mentioned, we do not favour periodic revaluation of property over the tenure as we are of the view that asset revaluation should take place when there is a sale incurring full transfer of property ownership. With regards to redemption, defaults and termination of contract, a revaluation decision would depend on the situations. The property need not be revalued if the customer does not intend to leave the house as the redemption amount would be the same as the balance outstanding. The property would be revalued when the customer intends to leave the house and in cases of default and termination of contract as this would involve the sale of the property. The residual amount will be shared between the customer and the bank after deducting all outstanding arrears, liquidation costs including legal costs etc. based on the prevailing profit sharing ratio.

This paper also made a comparison between interest rates and average gross rental yields for properties in Kuala Lumpur for period 1984 to 2005 whereby it was seen that rental yields for all categories of houses are generally lower than BLR and average lending rate. Only condominiums have shown higher rental yields than market interest rates. This implies that the bank may use MMP for properties that have potential of high rental only. When not feasible, for the bank when rental rates fall short of interest rates, the MMP model can be implemented through cooperatives, as an investment avenue to address the social well being of its members.

\section{References}

Bendjilali, Boualem and Khan, Tariqullah (1995) Economics of Diminishing Musharakah. Research Paper No. 31.Jeddah: Islamic Research and Training Institute (IRTI), IDB.

Dunse, Neil and Jones, Colin (1998) " A Hedonic Price Model of Office Rents", Journal of Property Valuation and Investment, 16(1): 297-312.

ISRA Monograph Series: 1(2009) International Shariah Research Academy for Islamic Finance (ISRA).

Meera, Ahamed Kameel Mydin and Abdul Razak, Dzuljastri (2005) "Islamic Home Financing through Musharakah Mutanaqisah and Al-Bay' Bithaman Ajil Contracts: A Comparative Analysis", Review of Islamic Economics, 9(2): 5-30.

Usmani, Muhammad Taqi (2004) An Introduction To Islamic Finance, Maktab Maa'rul Quran, Karachi-Pakistan.

Yacuby, Shaikh Nizam and Usmani, Muhammad Taqi Usmani (1998) "Fatwa on Usage of LIBOR as a Benchmark". A Fatwa issued on 19 July.

al-Zuhayli, Wahaba (2003) Islamic Jurisprudence and Its Proofs, Dar al-Fikr, p. 33; 56. 


\section{Appendix (A)}

\section{Musharakah Mutanaqisah Partnership Computational Example}

Meera and Abdul Razak (2005) derived the formulas for the MMP as follows:

$P=$ Price of asset, e.g. a home

$B_{0}=$ Financier's contribution into the partnership

$C_{0}=$ Customer's contribution into the partnership

Therefore, $P=B_{0}+C_{0}$

$R=$ Periodic rental, e.g. monthly

$A=$ Additional periodic payment by customer to redeem the financier's equity faster

$M=R+A$, is therefore, the total periodic payment

Let $C_{i}=$ the customer's equity (ownership) of the asset in period $i$

Let the proportion of customer's equity in period $i, \quad r_{i}=\frac{C_{i}}{P}$

$C_{n}=(1+x)^{n} C_{0}+\left[\frac{(1+x)^{n}-1}{x}\right] A$

and, of course, the proportion of the customer's equity in the $n^{\text {th }}$ period is $r_{n}=\frac{C_{n}}{P}$

Rewriting equation (1), the number of periods taken by the customer to fully own the house is given by,

$$
\Rightarrow n=\frac{\ln \left(P+\frac{A}{x}\right)-\ln \left(C_{0}+\frac{A}{x}\right)}{\ln (1+x)}
$$

Once the rental, $R$, has been determined and the customer has decided on the period of partnership, i.e. the $n$, then the periodic amount the customer has to top up additionally is given by

$$
A=\frac{x\left[P-(1+x)^{n} C_{0}\right]}{(1+x)^{n}-1}
$$

and, the formula for determining the periodic payment is given by 
$\Rightarrow M=\frac{x(1+x)^{n} B_{0}}{(1+x)^{n}-1}$

The periodic rate of return for Mushārakah Mutanākisah Partnership is solely determined by the rental rate, $x=\frac{R}{P}$. Therefore, the

Internal Rate of Return (IRR) to bank $=\frac{R}{P}$

Also,

Total payment made to financier $=M n$

Total profit to financier $=M n-B_{0}$ 


\section{Appendix (B)}

Below are the summary of five semi-structured interviews with scholars in Islamic economics, fiqh (law) and Shariah advisers of Islamic banks regarding their opinion on using actual rental based on value of property for Musharakah Mutanaqisah home financing in place of interest as a bench mark.

\section{Question:}

"What is your opinion on using actual rental value of property for Musharakah Mutanaqisah home financing in place of interest as bench mark?"

\section{Respondent 1}

Using bench mark on property is a plus point for Musharakah Mutanaqisah home financing as it reflects the real value of property. But we must also ensure that the property market is not manipulated to ensure fairness to both parties

\section{Respondent 2}

Using rental based on actual value of property is better because it reflects the real market compared to interest rate. However we must ensure fairness to both parties. Currently, we are sill benchmarking against interest rate. We need to change our mind set.

\section{Respondent 3}

Yes, bank as far as possible should use rental based on the actual value of property to avoid interest. However interest rate can still be used as a point of reference only. It's best for both bank and customer to agree on whatever bench mark (interest or actual value of property) to be used. I would suggest that bank fixed upper and lower pricing limit as an alternative to interest rate which fluctuates dramatically".

\section{Respondent 4}

Pricing should be based on the market. Currently, we can use interest rate as a point of reference in the absence of an Islamic benchmark. However, we should be working towards our own benchmark which is free from interest.

\section{Respondent 5}

We should base as far as possible pricing to reflect the market. As in property, we should price rent following the demand and supply of house within the area. There should also be bargaining allowed between the lessor and lessee before the amount of rent is agreed upon. 


\section{Appendix (C)}

\section{Using Conventional Calculators for MMP: A Worked Example}

Price of House $=$ RM200,000

Rent $=\mathrm{RM} 1,000$ per month

\begin{tabular}{|c|c|}
\hline Conventional Mortgage \& BBA & Musharakah Mutanaqisah \\
\hline 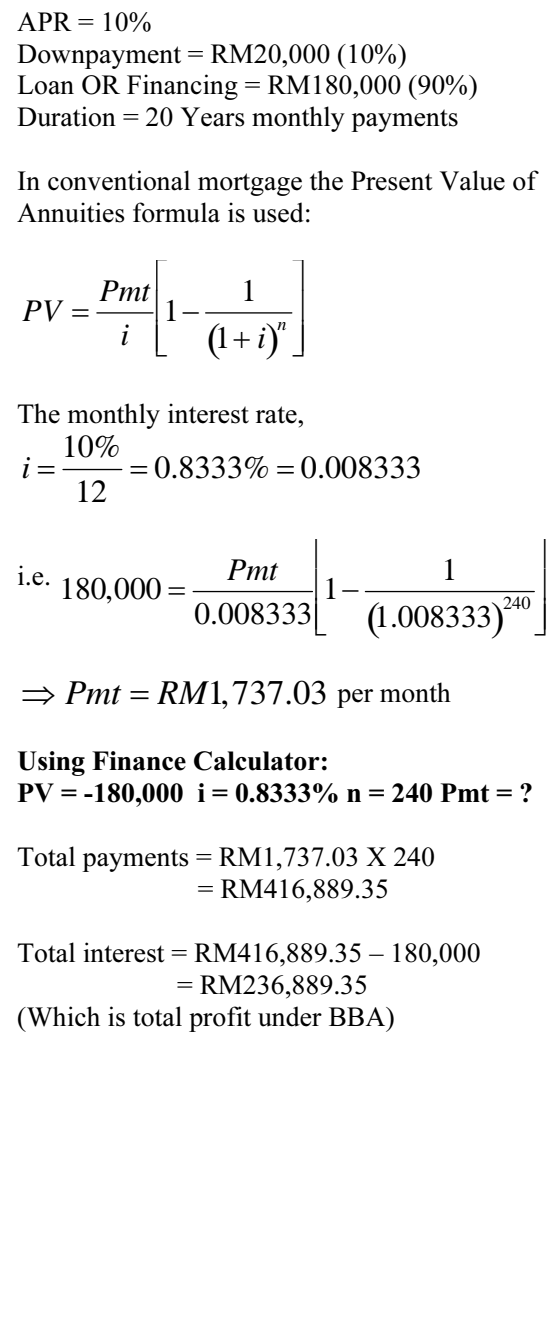 & 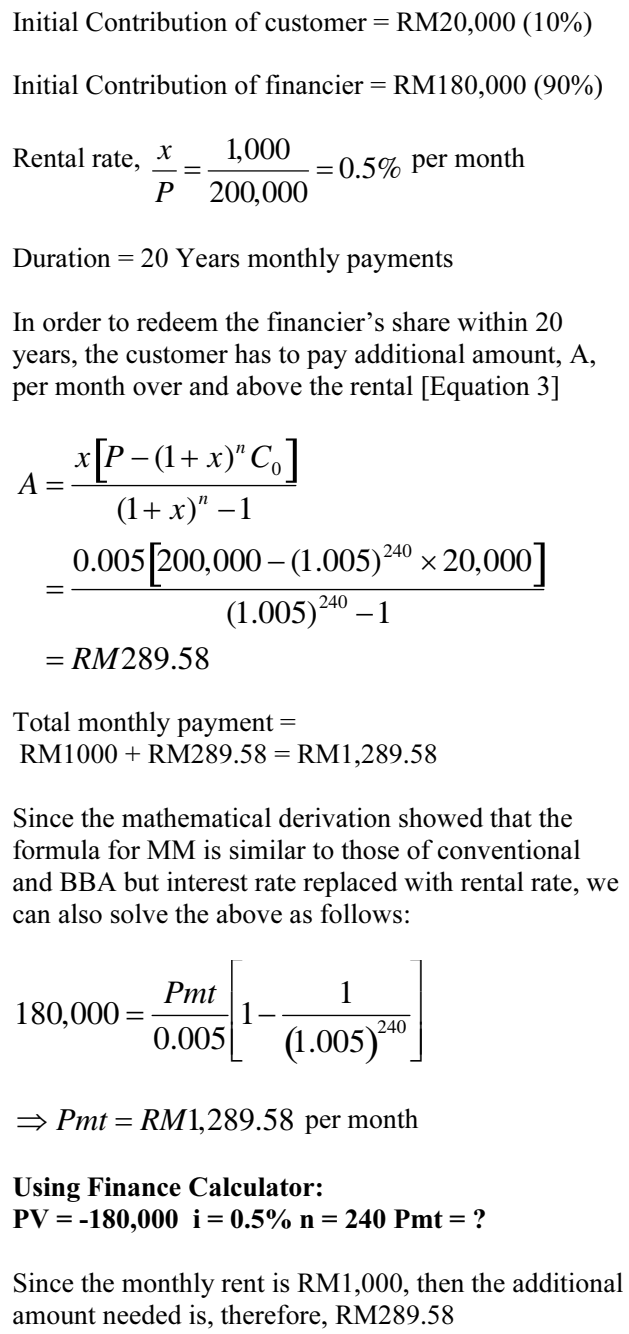 \\
\hline
\end{tabular}




\begin{tabular}{|c|c|}
\hline $\begin{array}{l}\text { Balance after } 10 \text { years }(120 \text { payments }) \\
\text { Under Conventional } \\
\begin{aligned} \text { Balance } & \left.=\frac{1,737.03}{0.008333} \mid 1-\frac{1}{(1.008333)^{120}}\right\rfloor \\
& =R M 131,443.76\end{aligned} \\
\text { Using Finance Calculator: } \\
\mathbf{i}=\mathbf{0 . 8 3 3 3 \%} \mathbf{P m t}=\mathbf{1 , 7 3 7 . 0 3} \mathbf{n}=\mathbf{1 2 0} \mathbf{P V}=\mathbf{?} \\
\text { Under BBA } \\
\text { The balance is simply the monthly payment } \\
\text { times the number of months } \\
\text { Balance }=\text { RM1,737.03 X } 120 \\
=\text { RM208,444.66 }\end{array}$ & 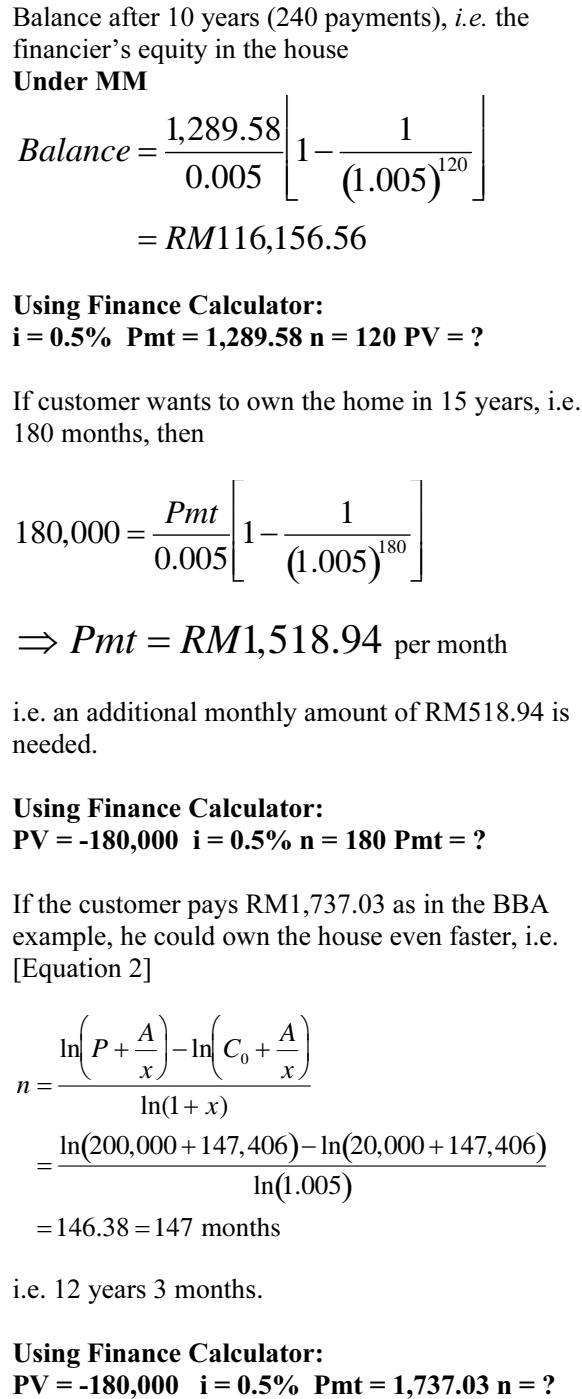 \\
\hline
\end{tabular}


التمويل العقاري بواسطة عقود المشاركة المنتاقصة: بعض قضايا تجريبية

\section{أحمد كميل ميدين ميرا، و ذوالجستري عبدالرزاق

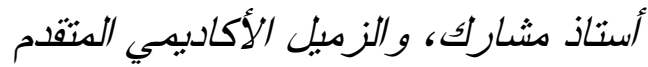

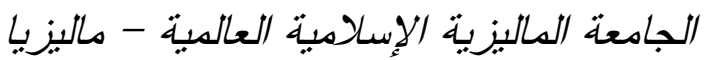

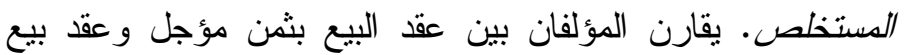

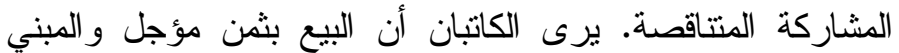

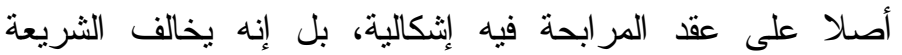
الإسلامية بالنسبة للعقود بعيدة الأجل. من جانب آخر ، يرى الكئه الكاتبان

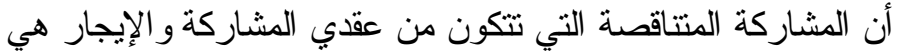

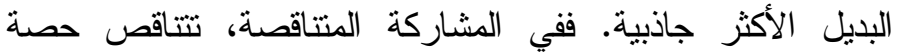
الممول في الأصول تدريجيا وفي المقابل تزداد حصة العيلة العميل تصاعديا. لقد أجمع جمهور العلماء على جولئ واز المشاركة المتناقصة

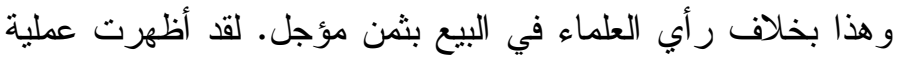

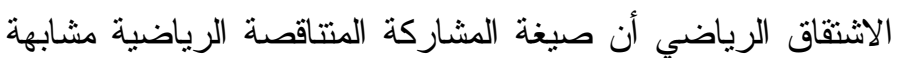

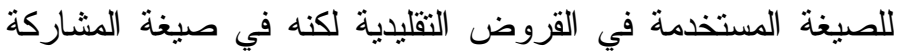

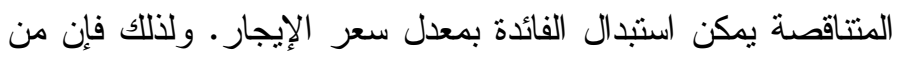

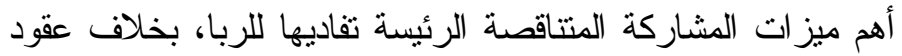

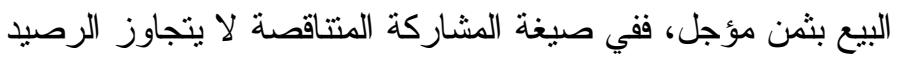

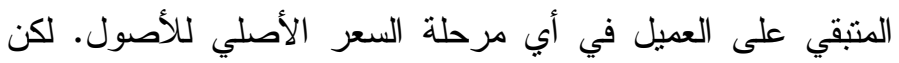

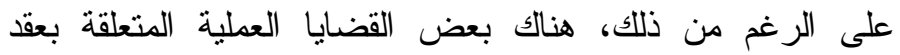

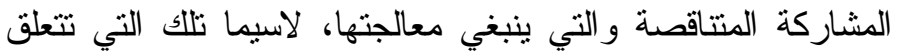

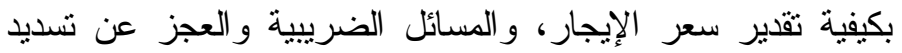

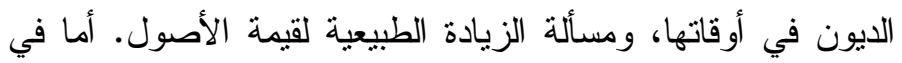

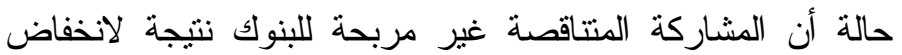

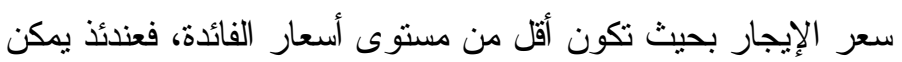

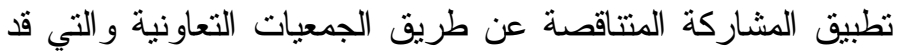
تعتبر وسيلة استثمارية لأعضاء الجمعية. 